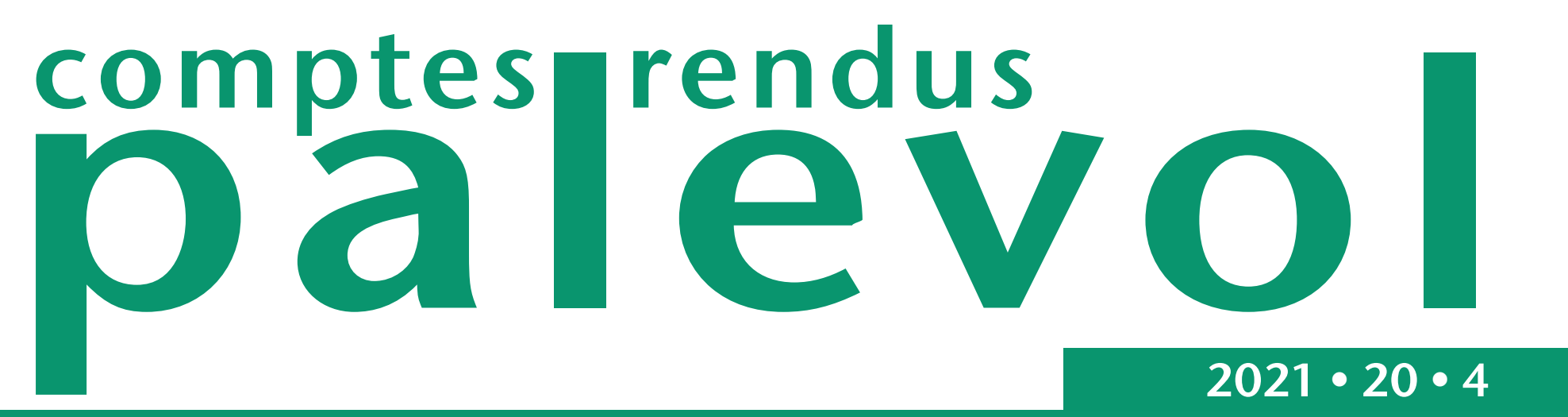

Fossil record of a Characiform in the Monte Hermoso Formation (lower Pliocene), Buenos Aires, Argentina. Palaeobiogeographical implications

Sergio BOGAN, Federico AGNOLIN \& Juan Marcos MIRANDE 
DiRECTEURS DE LA PUBLICATION / PUBLICATION DIRECTORS:

Bruno David, Président du Muséum national d'Histoire naturelle

Étienne Ghys, Secrétaire perpétuel de l'Académie des sciences

RÉDACTEURS EN CHEF / EDITORS-IN-CHIEF (*, took charge of the editorial process of the article/a pris en charge le suivi éditorial de l'article) Michel Laurin* (CNRS), Philippe Taquet (Académie des sciences)

AsSISTANTE DE RÉDACTION / AsSISTANT EDITOR: Adeline Lopes (Académie des sciences ; cr-palevol@academie-sciences.fr)

MISE EN PAGE / PAGE LAYOUT: Audrina Neveu (Muséum national d'Histoire naturelle ; audrina.neveu@mnhn.fr)

RÉDACTEURS ASSOCIÉS / ASSOCIATE EDITORS:

Micropaléontologie/Micropalaeontology

Maria Rose Petrizzo (Università di Milano, Milano)

Paléobotanique/Palaeobotany

Cyrille Prestianni (Royal Belgian Institute of Natural Sciences, Brussels)

Métazoaires/Metazoa

Annalisa Ferretti (Università di Modena e Reggio Emilia, Modena)

Paléoichthyologie/Palaeoichthyology

Philippe Janvier (Muséum national d'Histoire naturelle, Académie des sciences, Paris)

Amniotes du Mésozoïque/Mesozoic amniotes

Hans-Dieter Sues (Smithsonian National Museum of Natural History, Washington)

Tortues/Turtles

Juliana Sterli (CONICET, Museo Paleontológico Egidio Feruglio, Trelew)

Lépidosauromorphes/Lepidosauromorphs

Hussam Zaher (Universidade de São Paulo)

Oiseaux/Birds

Éric Buffetaut (CNRS, École Normale Supérieure, Paris)

Paléomammalogie (petits mammifères)/Palaeomammalogy (small mammals)

Robert Asher (Cambridge University, Cambridge)

Paléomammalogie (mammifères de moyenne et grande taille)/Palaeomammalogy (large and mid-sized mammals)

Lorenzo Rook (Università degli Studi di Firenze, Firenze)

Paléoanthropologie/Palaeoanthropology

Roberto Macchiarelli (Université de Poitiers, Poitiers)

Archéologie préhistorique/Prehistoric archaeology

Marcel Otte (Université de Liège, Liège)

COUVERTURE / COVER:

Made from the Figures of the article.

Comptes Rendus Palevol est indexé dans / Comptes Rendus Palevol is indexed by:

- Cambridge Scientific Abstracts

- Current Contents $\circledR$ Physical

- Chemical, and Earth Sciences ${ }^{\circledR}$

- ISI Alerting Services ${ }^{\circledR}$

- Geoabstracts, Geobase, Georef, Inspec, Pascal

- Science Citation Index ${ }^{\circledR}$, Science Citation Index Expanded ${ }^{\circledR}$

- Scopus ${ }^{\circledR}$

Les articles ainsi que les nouveautés nomenclaturales publiés dans Comptes Rendus Palevol sont référencés par / Articles and nomenclatural novelties published in Comptes Rendus Palevol are registered on:

- ZooBank ${ }^{\circledR}$ (http://zoobank.org)

Comptes Rendus Palevol est une revue en flux continu publiée par les Publications scientifiques du Muséum, Paris et l'Académie des sciences, Paris Comptes Rendus Palevol is a fast track journal published by the Museum Science Press, Paris and the Académie des sciences, Paris

Les Publications scientifiques du Muséum publient aussi / The Museum Science Press also publish:

Adansonia, Geodiversitas, Zoosystema, Anthropozoologica, European Journal of Taxonomy, Naturae, Cryptogamie sous-sections Algologie, Bryologie, Mycologie.

L'Académie des sciences publie aussi / The Académie des sciences also publishes:

Comptes Rendus Mathématique, Comptes Rendus Physique, Comptes Rendus Mécanique, Comptes Rendus Chimie, Comptes Rendus Géoscience, Comptes Rendus Biologies.

Diffusion - Publications scientifiques Muséum national d'Histoire naturelle

CP 41 - 57 rue Cuvier F-75231 Paris cedex 05 (France)

Tél. : 33 (0)1 40794805 / Fax: 33 (0)140793840

diff.pub@mnhn.fr / https://sciencepress.mnhn.f

Académie des sciences, Institut de France, 23 quai de Conti, 75006 Paris.

(C) Publications scientifiques du Muséum national d'Histoire naturelle / (c) Académie des sciences, Paris, 2021

ISSN (imprimé / print): 1631-0683/ ISSN (électronique / electronic) : 1777-571X 


\title{
Fossil record of a Characiform in the Monte Hermoso Formation (lower Pliocene), Buenos Aires, Argentina. Palaeobiogeographical implications
}

\author{
Sergio BOGAN \\ Fundación de Historia Natural "Félix de Azara", Departamento de Ciencias Naturales \\ y Antropología, Universidad Maimónides; Hidalgo 775 piso 7 , \\ C1405BDB, Buenos Aires (Argentina) \\ sergiobogan@yahoo.com.ar (corresponding author) \\ Federico AGNOLIN \\ Fundación de Historia Natural "Félix de Azara", Departamento de Ciencias Naturales \\ y Antropología, Universidad Maimónides; Hidalgo 775 piso 7 , \\ C1405BDB, Buenos Aires (Argentina) \\ and Laboratorio de Anatomía Comparada y Evolución de los Vertebrados, \\ Museo Argentino de Ciencias Naturales "Bernardino Rivadavia", \\ Av. Ángel Gallardo, 470, C1405DJR, Buenos Aires (Argentina) \\ fedeagnolin@yahoo.com.ar \\ Juan Marcos MIRANDE \\ Fundación Miguel Lillo - Unidad Ejecutora Lillo (CONICET), \\ San Miguel de Tucumán, 4000 Tucumán (Argentina) \\ mcmirande@gmail.com \\ Submitted on 7 August 2019 | Accepted on 7 January 2020 | Published on 2 February 2021
}

urn:Isid:zoobank.org:pub:5EC76CBA-F08F-40B9-B509-F70FCCB48949

Bogan S., Agnolin F. \& Mirande M. J. 2021. - Fossil record of a Characiform in the Monte Hermoso Formation (lower Pliocene), Buenos Aires, Argentina. Palaeobiogeographical implications. Comptes Rendus Palevol 20 (4): 49-55. https:// doi.org/10.5852/cr-palevol2021v20a4

\section{ABSTRACT}

The fossil record of fishes from the Farola de Monte Hermoso locality (lower Pliocene) in the southern Buenos Aires province, Argentina, shows an unusual composition. The locality at the southern boundary of the Brazilian Ichthyogeographic Realm. However, its fossil record is composed of fossil fishes that are not necessarily related to Brazilian lineages, namely indeterminate siluriforms, trichomycterid catfishes, and percomorphaceans. The aim of the present contribution is to describe and report for

KEY WORDS

Characidae, Pliocene,

Farola de Monte Brazilian Ichthyofauna. the first time isolated specimens belonging to Characidae fishes. In the Pampean region the fossil record of characids is restricted to Oligosarcus Günther, 1864 sp. from the late-middle Pleistocene. The present finding fills a temporal gap between the Paleogene and Quaternary reports and indicates that Brazilian fish lineages were present in the area by early Pliocene times, and may constitute an indirect evidence of the evolution of the basins in the southern Pampean Area. 


\begin{abstract}
RÉSUMÉ
Registre fossile de Characiformes dans la Formation de Monte Hermoso (Pliocène inferieur), Buenos Aires, Argentine. Implications paléobiogéographiques.

Le registre fossile de poissons de la localité de Farola de Monte Hermoso (Pliocène inférieur) dans la province méridionale de Buenos Aires, Argentine, est encore biaisé. Il est situé à la limite méridionale du domaine ichthyogéographique brésilien. Cependant, son registre fossile est composé de poissons fossiles qui ne sont pas nécessairement reliés aux lignées brésiliennes, en particulier siluriformes indéterminés, poissons-chats trichomyctéridés et percomorphacéens. Le but de la présente contribution est de décrire et mentionner des spécimens isolés appartenant aux poissons Characidés.

MOTS CLÉS

Characidae, Pliocène,

Farola de Monte

Hermoso,

Ichthyofaune brésilienne.

Dans la région de la Pampa, le registre fossile des Characidés est restreint à Oligosarcus Günther, 1864 sp. du Pléistocène moyen tardif. Les présentes découvertes comblent un vide temporel entre les registres au Paléogène et au Quaternaire et indiquent que des lignées de poissons brésiliens étaient présents dans la zone au Pliocène inférieur et peuvent constituer une preuve indirecte de l'évolution des bassins dans le domaine méridional de la Pampa.
\end{abstract}

\section{INTRODUCTION}

The fossil record of Farola de Monte Hermoso locality (lower Pliocene) has been well known since the visit of Charles Darwin in 1832. The fossil record of fishes is relatively good; since the $19^{\text {th }}$ century, authors have reported articulated remains (Moreno 1889), siluriform spines and perches (Ameghino 1898; Arratia \& Cione 1996).

More recently, the record of fossil fishes has improved with new findings and more detailed taxonomic studies, including the description of trichomycterid catfishes (Bogan \& Agnolin 2009), and a new percichthyid genus and species (Agnolin et al. 2014). Tomassini et al. (2013) mentioned, but did not describe, indeterminate siluriforms and characid remains. The aim of the present contribution is to describe characiform fossils mentioned by Tomassini et al. (2013). Because previous authors suggested that the Farola de Monte Hermoso locality may be related to the Río Colorado paleobasin, and consequently may have been related to the Austral Ichthyogeographic region, the presence of a characiform has important palaeobiogeographical implications.

\section{MATERIAL AND METHODS}

The specimens described here were non-selectively collected by microsectors, due to screening with superposition of sieves with different thickness meshes (2000, 1000, 500 and 250 microns). Sediments were previously washed with water to loosen the consistency of the rock, release clasts, and disintegrate it.

\section{LOCALITY AND HORIZON}

Farola Monte Hermoso (3900'30"S, 61 30 '10"W) is located on the Atlantic coast, approximately $53 \mathrm{~km}$ from the city of Bahía Blanca and approximately $12 \mathrm{~km}$ southwest of Pehuen Có beach (Buenos Aires Province, Argentina). This locality has been studied by numerous authors (e.g. Darwin 1846; Ameghino 1898;
Bonaparte 1960), who described the diversity and abundance of vertebrate fossil remains yielded by this locality. In addition, Farola Monte Hermoso constitutes the type locality of the Monte Hermoso Formation (lower-middle Pliocene) (Zavala \& Navarro 1993) and of the Montehermosan and lower Chapadmalalan stage/age, corresponding to the late Miocene-early Pliocene and early Pliocene respectively (Cione $\&$ Tonni 2005).

The Monte Hermoso Formation is constituted of sedimentary deposits that represent floodplain and channel subenvironments within a meandering fluvial system (Zavala \& Navarro 1993). The specimens studied here come from deposits ranging in thickness from 5 to $60 \mathrm{~cm}$, including clastic-supported breccias, composed of embedded silty and sandy intraclasts over $15 \mathrm{~cm}$ in diameter, some of them rounded off, and a silt-sandy matrix. In some sections, these deposits have a massive structure, while in others they have a planar cross-bedding. This level is correlated with the St facies of Zavala \& Navarro (1993) and is included in the Neocavia depressidens Parodi \& Kraglievich, 1948 Biozone, the biostratigraphic basis of the stage/age lower Chapadmalalan, (early Pliocene) (Cione \& Tonni 2005).

INSTITUTIONAL ABBREVIATIONS

MD-FM Museo Municipal de Ciencias Naturales "Carlos Darwin”, Punta Alta, Buenos Aires.

\section{SYSTEMATIC PALEONTOLOGY}

\section{Order CHARACIFORMES sensu Fink \& Fink, 1996 Family CHARACIDAE sensu Mirande, 2019}

Genus and species indeterminate

REFERRED MATERIAL. - MD-FM-19-03, complete isolated right premaxilla (Fig. 1A-C); and MD-FM-19-04, incomplete left maxilla lacking portion of the alveolar ramus (Fig. 1D-F).

\section{DESCRIPTION}

Specimens were found disarticulated and isolated, and thus, it is uncertain if they belonged to the same individuals. 
A
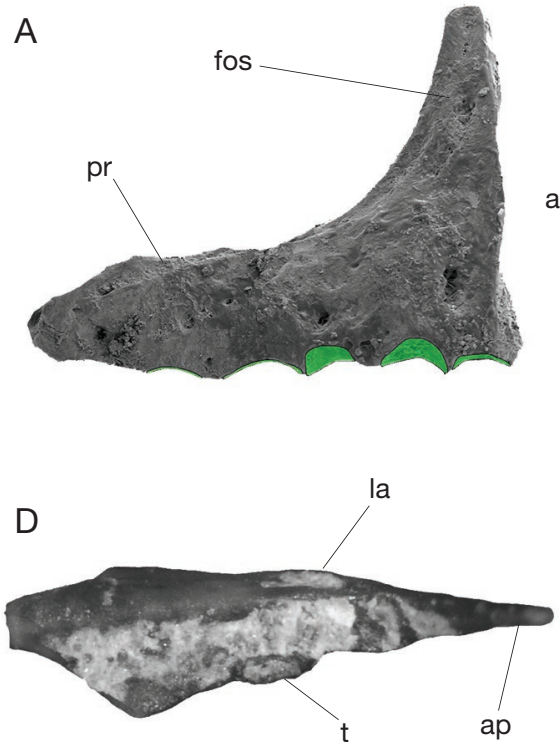
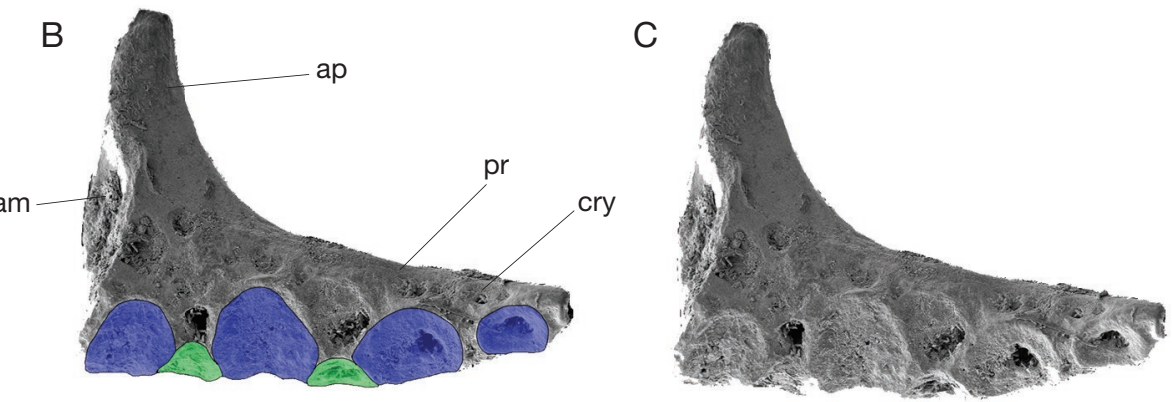

E

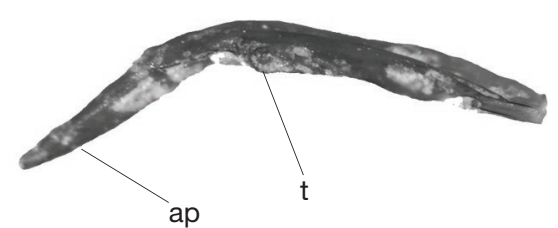

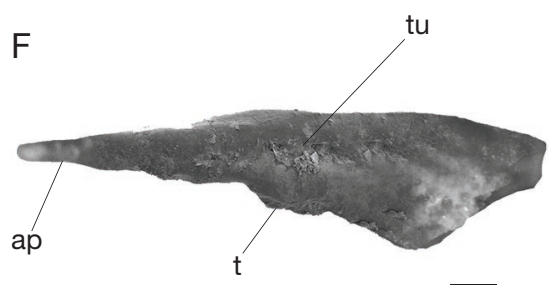

FIG. 1. - A-C, MD-FM-19-03, complete isolated right premaxilla in A, lateral, B and C, medial views. Outer tooth row shaded in green; inner tooth row shaded in violet. D-F, MD-FM-19-04, incomplete left maxilla in D, medial, E, ventral, and F, lateral views. Abbreviations: am, shaped articular surface for a ligamentary articulation with the mesethmoid; ap, ascending process; cry, crypt; fos, fossa; la, attachment site of the ligamentum primordiale; pr, premaxillary ramus; t, tooth; tu, tubule. Scale bars: $0.1 \mathrm{~mm}$.

\section{Premaxilla}

The premaxilla is subtriangular in contour with a short and narrow ascending process that surpasses half the length of the premaxillary ramus. The ascending process is subtriangular in contour and has a nearly straight anterior margin.

The external surface of the ascending process bears a shallow fossa, and the alveolar ramus has four large external fossae and irregularly disposed smaller pits. In lateral view, near the dorsal margin of the premaxilla, a well-defined and delimited groove extends along the bone. This groove runs subparallel to the margin of the premaxilla and extends nearly to the mid-length of the ascending process.

The medial surface of the ascending process has a cupshaped articular surface for a ligamentous articulation with the mesethmoid, that differs from the interdigitating articulation exhibited by members of the Agoniatidae, Bryconidae, and Chalceidae (Mirande 2010, 2019). There are several crypts for the formation of replacement teeth.

The posterior end of the premaxilla has a concave notch for articulation with the maxilla, and lacks any sign of a posterior pedicle, as occurs in the Alestidae (Zanata \& Vari 2005).

In occlusal view, there are two main tooth rows, each one having four tooth positions. The positions of the inner row, except for the second tooth, are smaller than those of the outer series. The outer row elements are subequal in size and shape, whereas those of the inner row are dissimilar to each other. There is no evidence of teeth outside the occlusal surface of the premaxilla.

\section{Maxilla}

This is a long element with an acute anterior process. The base of a single, broad tooth is preserved at the ventral margin of the bone. The dorsal and ventral margins gradually diverge along the preserved portion of bone. The dorsal margin shows the anterior attachment site of the ligamentum primordiale as a small projection. The posteriormost portion of the maxilla is not preserved. In medial view, there is a single small dorsal tubule for the passage of blood vessels.

\section{DISCUSSION}

MD-FM-19-03 has a short premaxilla with a short but welldefined ascending process, lacking medial interdigitations to articulate with contralateral premaxilla, presence of teeth in more than one row, teeth from inner row larger than those of the outer row, and the replacement teeth are formed in crypts, a combination of characters shared with characids (Vari 1979; Fink \& Fink 1996; Buckup 1998; Zanata \& Vari 2005; Mirande 2019). Further, MD-FM-19-03 differs from alestids in lacking the posterolateral portion of the premaxilla extended in a pedicle-like process, and maxilla without several teeth and having a single anterior process without an anterior notch (Zanata \& Vari 2005; Mirande 2010; Weiss et al. 2012). MD-FM-19-03 differs from Roeboides Günther, 1864, and the Exodontinae in lacking any sign of outer mammilliform teeth outside the mouth, a condition associated with lepidophagous habits (Miquelarena 1986; Mirande 2010). Specimen MD-FM-19-03 differs from most Aphyocharacinae and all Cheirodontinae in having two functional rows of teeth (vs one single row; Malabarba 1998).

The presence of only four teeth in the inner premaxillary series is a feature that MD-FM-19-03 shares with the characid genus Gymnocharacinus Steindachner, 1903 and most members of the Stevardiinae (e.g. Acrobrycon Eigenmann \& Pearson, 1924, Bryconamericus Eigenmann, 1907, Diapoma 
Cope, 1894, Markiana Eigenmann, 1903). This character has been used since Eigenmann $(1917)$ and Géry $(1966,1977)$ to diagnose some characid genera and characid clades. Malabarba and Weitzman (2003) proposed the presence of four teeth in the inner premaxillary tooth row as a synapomorphy for their clade $\mathrm{A}$, which was subsequently recognized as a subfamily by Mirande (2010). Some genera of Stevardiinae, however, have more than four teeth in the inner premaxillary row, including Mimagoniates Regan, 1907, Nantis Mirande, Aguilera \& Azpelicueta, 2006, and Pseudocorynopoma Perugia, 1891, among those living in the Río de la Plata basin.

MD-FM-19-03 is distinguishable from several species of Bryconamericus (e.g. Bryconamericus exodon Eigenmann, 1907, B. stramineus Eigenmann, 1908), Hemibrycon Günther, 1864 (e.g. Hemibrycon dariensis Meek \& Hildebrand, 1916, H. surinamensis Géry, 1962), and Knodus Eigenmann, 1911 (e.g. Knodus breviceps (Eigenmann, 1908)) in lacking anteriorly displaced teeth in the first row that result in a zig-zag-pattern of teeth (Mirande 2010). Two rows of premaxillary rows distinguishes it from the Alestidae, Bryconidae, Chalceidae, and Triportheus Cope, 1872 (Agoniatidae) (Mirande 2010, 2019). The ascending process of the premaxilla is much shorter and forms a right angle with the alveolar ramus. This combination of features, together with the presence of four teeth in the posterior premaxillary row of teeth, is rare or unique among known members of the Characidae. In Nantis and all examined Stevardiinae having four teeth in the inner premaxillary row, the ascending process is almost as long as the alveolar ramus and forms an acute angle with it that, together with the contralateral premaxilla, gives space for the usually triangular anterior mesethmoid process (Mirande 2010). Similar morphology was observed in other genera bearing more than four teeth in the inner premaxillary row, as in the examined species of Andromakhe Terán, Benitez \& Mirande, 2020, Astyanax Baird \& Girard, 1859, Gymnocorymbus Eigenmann, 1908, Hemigrammus Gill, 1858, Hyphessobrycon Durbin, 1908, Moenkhausia Eigenmann, 1903, and Psalidodon Eigenmann, 1911. Some stevardiines, such as Mimagoniates (Glandulocaudini) and Pseudocorynopoma (Stevardiini), have a relatively long alveolar ramus, but these have more than four teeth in the inner premaxillary row.

The almost straight angle between the alveolar and ascendent premaxillary rami suggests a narrow anterior mesethmoid process, comparable to that of Gymnocharacinus or Mimagoniates, among the examined genera. However, MD-FM-19-03 differs from Gymnocharacinus in having a long alveolar ramus, the outer tooth row with four (rather than three elements), and inner teeth that do not gradually diminish in size toward the posterior end of the premaxilla (Miquelarena \& Arámburu 1983). As mentioned above, the preserved premaxilla differs from extant members of Mimagoniates by having only four premaxillary teeth in the inner row (Mirande 2010).

Members of the fossil genera Bryconetes Weiss, Malabarba \& Malabarba, 2014 and Paleotetra Weiss, Malabarba \& Malabarba, 2012 (Eocene-Oligocene) have also four teeth in the inner premaxillary row (Weiss et al. 2012, 2014). Among those taxa, the premaxilla is known only in the species of Paleotetra
(Weiss et al. 2012: figs 4A; 8C). It shows similar proportions to the one herein described but has a more acute angle between the alveolar and ascendent rami, suggesting the possession of a broader anterior mesethmoid process.

The maxilla (MD-FM-19-04) has fewer taxonomically useful features. The most striking character is the presence of an insertion site for a single, apparently broad tooth. This differs from most characids and especially from the taxa sharing some features with the premaxilla herein described. Bryconetes and Paleotetra have several maxillary teeth (Weiss et al. 2012, 2014), whereas the Stevardiinae have usually more than two teeth, with narrow base. A single broad maxillary tooth is present in some species of Psalidodon, such as $P$. puka (Mirande, Aguilera \& Azpelicueta, 2007) and P. pynandi (Casciotta, Almirón, Bechara, Roux \& Ruiz Diaz, 2003) (Casciotta et al. 2003; Mirande et al. 2007; Terán et al. 2020). However, Psalidodon species have a branched maxillary vascular tubule (Mirande 2010: fig. 54), different from the fossil, which has only the dorsal ramus of this canal, the commonest condition among the Characidae. Some members of the Cheirodontinae (such as Cheirodon Girard, 1855) have a single broad maxillary tooth, but they almost universally have an abruptly expanded maxillary lamella just posterior to the maxillary tooth or teeth (Mirande 2010: fig. 53), while in the preserved fossil that expansion is gradual. The ligamentum primordiale is usually attached dorsally to the maxilla in the region between the ascending process and posterior lamella (the insertion region may be deduced for Astyanax, Markiana, and Serrapinnus Malabarba, 1998 in Mirande 2010: fig. 54; 55; 53, respectively). In the fossil, the attachment of the ligament appears to have been just dorsal to the dentigerous region, which is more posteroventrally located than in the mentioned genera.

The fossil herein described presents a mosaic of several diagnostic features partially shared with different taxa, as the Eocene-Oligocene stem-Characidae genera Bryconetes and Paleotetra, most members of the Stevardiinae, some species of Psalidodon and the nominotypical species of the subfamily Gymnocharacinae Gymnocharacinus bergii Steindachner, 1903. However, the isolated and fragmentary nature of the specimens described here do not allow us to identify the material beyond the family level. Indeed, the unusual combination of features of the maxilla and premaxilla leaves open the possibility of both remains belong to different species.

\section{PALAEOBIOGEOGRAPHICAL IMPLICATIONS}

The Characidae are the most diverse family of Neotropical fishes, with more than 1150 known species (Eschmeyer \& Fong 2017; Mirande 2019). In contrast to current diversity, the fossil record of characids is patchy. The oldest possible characids are represented by isolated teeth from latest Cretaceous Bolivian deposits (Gayet et al. 2001; Gayet \& Meunier 2003). More complete characids are known from the Eocene-Oligocene Entre-Corregos Formation and the Oligocene Tremembé Formation of southeastern Brazil, where four different paleospecies have been recognized (Malabarba 1998; Weiss et al. 2012, 2014). 
In the Pampean region, the fossil record of characids is restricted to an indeterminate species of Oligosarcus Günther, 1864 from the Pleistocene of Centinela del Mar (Bogan \& de los Reyes 2009). The present finding constitutes an important addition to this meagre record. It fills a temporal gap between the Paleogene and Quaternary records and yields new information about the extension of paleobasins as well as the past distribution of the Brazilian ichthyofaunas.

The locality of Farola Monte Hermoso is currently in the Pampean phytogeographic and zoogeographic district (Cabrera \& Willink 1980). Ringuelet (1961) considered this district an ecotone that shared considerable similarities with northern latitudes, representing a depauperate Chacoan District. The fossil record of Farola de Monte Hermoso is in concordance with Ringuelet's hypothesis, indicating that the area had a warmer climate, covered by wooded xeric areas, than occurs today in the Chacoan region, but probably with greater humidity (Tonni 1974; Pascual 1984; Albino 1992; Pascual et al. 1996; Tomassini et al. 2011; Bogan \& Agnolin 2019). By Pleistocene times in the Pampean Area, when the climate became more rigorous, the Chacoan faunistic influence from the Pampas greatly diminished (Ringuelet 1961).

The Neotropical region is traditionally divided into the Austral and Brazilian ichthyogeographic subregions (Ringuelet 1975; Menni 2004). Most of the diversity of freshwater fishes is restricted to the Brazilian subregion, the area to which characid fishes are now confined (Ringuelet 1975; Almirón et al. 1997). The Pampean region constitutes the southernmost limit of several freshwater fish clades that are sensitive to low temperatures, as is the case for characids (Ringuelet 1961). South to the Salado basin, characids are represented by four species (Bryconamericus iheringii Boulenger, 1877, Cheirodon interruptus (Jenyns, 1842), Oligosarcus jenynsii (Günther, 1864), and Psalidodon pampa (Casciotta, Almirón \& Azpelicueta, 2005)), some of which may belong to recent anthropical introductions (Casciotta et al. 1999 ; Bogan et al. 2020).

The Patagonian Naked Characin (Gymnocharacinus bergii) is a species endemic to the Valcheta stream, a thermal watercourse located in the northern Río Negro province of Patagonia (Menni 2004). This species is the only characid that is not included in the Brazilian Ichthyogeographical Area and is considered a relic of previously widespread Brazilian fish faunas (Menni 2004). The presence of loricariids and other siluriforms in northern Patagonia and the southern Buenos Aires pampas by late Miocene times (Cione et al. 2005; Bogan \& Agnolin 2019) is in agreement with this, as indicative of warmer climatic conditions in the area and a consequently widespread geographical distribution of Brazilian fishes. In this sense, Cione et al. (2005; see also Bogan \& Agnolin 2019) hypothesized that the rivers of northern Patagonia during the late Miocene were hydrographically connected to more northern basins at some point. This explains the presence of Brazilian fishes in northern Patagonia by late Neogene times.

Fossil fishes from Farola de Monte Hermoso are represented by taxa that are not necessarily related to Brazilian lineages, including trichomycterid siluriforms and percichthyids, which are widely distributed in Andean, Patagonian and Cuyan basins (Bogan \& Agnolin 2009; Agnolin et al. 2014). The presence of a characid constitutes the first unequivocal evidence of Brazilian fishes in the area.

It is worth noting that the combination of characters exhibited by the material described here is different from those of extant austral characids, including Gymnocharacinus and those of the southern Pampean region (i.e., Bryconamericus, Cheirodon, Oligosarcus, and Psalidodon).

The present record is in concordance with the hypothesis of a widespread distribution of Brazilian ichthyofaunas, specifically characid fishes.

\section{CONCLUSIONS}

Since the first discovery of a fossil fish 120 years ago, the Farola de Monte Hermoso locality has yielded a large number of fossil fishes. However, they still are insufficiently known and new discoveries in the area are welcome.

The present finding constitutes the first undisputable evidence of a characid fish from the early Pliocene Farola de Monte Hermoso locality. It further indicates that Brazilian fish lineages were present in the area by early Pliocene times and may constitute an indirect evidence of the evolution of basins in the southern Pampean Area.

\section{Acknowledgements}

We thank A. Giacchino (Fundación Azara-Universidad Maimónides) for his constant support. T. Manera (Universidad Nacional del Sur) helped with logistic support during the development of the present manuscript. Special thanks to R. Tomassini, who made the SEM photographs and contributed to the geological settings of the present contribution. We deeply thank L. Berbach and R. Caputo (Museo "Carlos Darwin", Punta Alta) for their help with the collection numbers of specimens described here. We also thank two anonymous reviewers, and the editor M. Laurin for their enlightening comments on the manuscript.

\section{REFERENCES}

Agnolin F. L., Bogan S., Tomassini R. L. \& Manera T. 2014. Nuevo Percichthyidae (Teleostei, Percoidei) del Plioceno temprano de la provincia de Buenos Aires (Argentina) y sus implicancias biogeográficas. Revista del Museo Argentino de Ciencias Naturales 16 (1): 19-31. http://hdl.handle.net/11336/6583

AlBino A. M. 1992. - Primer registro de un Boidae (Reptilia: Serpentes) en el Plioceno de la provincia de Buenos Aires. Pesquisas em Geociências 10: 106-109. https://doi.org/10.22456/18079806.21327

Almirón A., Azpelicueta M., Casciotta J. R. \& López Cazorla A. 1997. - Ichthyogeographic boundary between the Brazilian and Austral subregions in South America. Biogeographica 73 (1): 23-30. AMEGHINO F. 1898. - Sinopsis geológico-paleontológica de la Argentina. Segundo Censo Nacional de la República Argentina, La Plata: $115-228$. 
ARratia G. \& CiOne A. 1996. - The record of fossil fishes of southern South America. Münchner Geowissenschaftliche Abhandlungen 30: 9-72.

Bogan S. \& Agnolin F. L. 2009. - Primer registro fósil de la familia Trichomycteridae (Teleostei: Siluriformes; Plioceno) en la Formación Monte Hermoso, Argentina. Revista del Museo Argentino de Ciencias Naturales 11 (2): 193-198.

Bogan S. \& DE los Reyes M. L. 2009. - Primer registro fósil del género Oligosarcus Günther, 1864 (Teleostei: characiformes). Studia Geologia Salmanticensia 45 (1): 41-52.

BogAN S. \& AGNOLIN F. L. 2019. — Armored catfish (Siluriformes: Loricariidae) from the Miocene of southern Pampas and its palaeobiogeographical implications. Swiss Journal of Palaeontology 138: 325-330. https://doi.org/10.1007/s13358-019-00196-2

Bogan S., Agnolin F. L., Cenizo M., Tassara D., Giacchino A. 2020. - A Pleistocene freshwater ichthyofaunal assemblage from central Argentina: What kind of fishes lived in the Pampean lagoons before the extinction of the megafauna?. PLoS ONE 15 (7): e0235196. https://doi.org/10.1371/journal.pone.0235196

BONAPARTE J. 1960. — La sucesión estratigráfica de Monte Hermoso (provincia de Buenos Aires). Acta Geológica Lilloana 3: 273-287.

BuCKUP P. A. 1998. - Relationships of the Characidiinae and phylogeny of characiform fishes (Teleostei: Ostariophysi), in Malabarba L. R., Reis R. E., Vari R. P., Lucena Z. M. S. \& LUCENA C. A. S. (eds), Phylogeny and classification of Neotropical fishes. Edipucrs, Porto Alegre: 123-144.

Cabrera A. L. \& Willink A. 1980. - Biogeografía de America Latina. Secretaría General de la Organización de los Estados Americanos, Washington D. C., 123 p.

Casciotta J. R., Almirón A., Cione A. \& Azpelicueta M. M. 1999. - Brazilian freshwater fish assemblages from southern pampean area, Argentina. Biogeographica 75 (2): 67-78.

Casciotta J. R., Almiron A. E., Bechara J. A., Roux J. P. \& RuIZ DiAz F. 2003. - Astyanax pynandi sp. n. (Characiformes, Characidae) from the Esteros del Iberá wetland, Argentina. Revue suisse de Zoologie 110 (4): 807-816.

Cione A. L. \& TonNi E. P. 2005. - Bioestratigrafía basada en mamíferos del Cenozoico superior de la provincia de Buenos Aires, Argentina. Geología y Recursos Minerales de la Provincia de Buenos Aires 11: 183-200.

Cione A. L., Azpelicueta M. M., Casciotta J. R. \& Dozo M. T. 2005. - Tropical freshwater teleosts from Miocene beds of eastern Patagonia, southern Argentina. Geobios 38: 29-42. https:// doi.org/10.1016/j.geobios.2003.08.005

DARWIN C. 1846. - Geological observations on South America: Being the third part of the geology of the voyage of the Beagle, under the command of Capt. Fitzroy, RN during the years 1832 to 1836. Vol. 3. Createspace Independent Publishing Platform.

Eigenmann C. H. 1917. - The American Characidae. Memoirs of the Museum of Comparative Zoology 43: 1-102.

EschmeYer W. N. \& FONG J. D. 2017. - Species by Family/ Subfamily in the Catalog of Fishes. Catalog of Fishes. Available at http://researcharchive.calacademy.org/research/ichthyology/ catalog/SpeciesByFamily.asp

FINK S. V. \& FINK W. L. 1996. - Interrelationships of the ostariophysan fishes (Teleostei), in STIASSNY M. L. J., PARENTI L. R. \& JOHNSON G. D. (eds), Interrelationships of Fishes. Academic Press, San Diego, CA: 209-249.

Gayet M. \& Meunier F. J. 2003. - Palaeontology and palaeobiogeography of catfishes, in ARratia G., KaPOOR B. G., Chardon M. \& Diogo R. (eds), Catfishes. Science Publishers, Enfield, New Hampshire: 491-522.

Gayet M., Marshall L. G., Sempere T., Meunier F. G., Cappetta H. \& RaGE J.-C. 2001. — Middle Maastrichtian vertebrates (fishes, amphibians, dinosaurs and other reptiles, mammals) from Pajcha Pata (Bolivia). Biostratigraphic, palaeoecologic and palaeobiogeographic implications. Palaeogeography, Palaeoclimatology, Palaeoecology 169: 39-68. https://doi.org/10.1016/S0031-0182(01)00214-0
GÉRY J. 1966. - A review of certain Tetragonopterinae (Characoidei), with the description of two new genera. Ichthyologica 37 (5): 211-236

GÉRY J. 1977. - Characoids of the World. TFH Publications, Neptune City, 672 p.

Malabarba L. R. \& Weitzman S. H. 2003. - Description of a new genus with six new species from southern Brazil, Uruguay and Argentina, with a discussion of a putative characid clade (Teleostei: Characiformes: Characidae). Comunicaçōes do Museu de Ciências e Tecnologia da PUCRS 16 (1): 67-151.

Malabarba L. R. 1998. - Monophyly of the Cheirodontinae, characters and major clades (Ostariophysi: Characidae), in Malabarba L. R., Reis R. E., Vari R. P., Lucena Z. M. S. \& LuCENA C. A. S. (eds), Phylogeny and classification of Neotropical fishes. Edipucrs, Porto Alegre: 193-233.

MenNi R. C. 2004. - Peces y ambientes en la Argentina continental. Monografias del Museo Argentino de Ciencias Naturales 5: 1-316.

Miquelarena A. M. 1986. - Estudio de la dentición de peces Characoideos de la República Argentina. Biologia Acuática 8: 1-60.

Miquelarena A. M. \& Arámburu R. H. 1983. - Osteologia y lepidologia de Gymnocharacinus bergi (Pisces Characidae). Limnobios 2 (7): 491-512.

Mirande J. M. 2010. — Phylogeny of the family Characidae (Teleostei: Characiformes): from characters to taxonomy. Neotropical Ichthyology 8: 385-568. https://doi.org/10.1590/S167962252010000300001

Mirande J. M. 2019. - Morphology, molecules and the phylogeny of Characidae (Teleostei, Characiformes). Cladistics 35: 282-300. https://doi.org/10.1111/cla.12345

Mirande J. M., Aguilera G. \& Azpelicueta M. M. 2007. A new species of Astyanax (Characiformes: Characidae) from the endorheic Río Salí basin, Tucumán, northwestern Argentina. Zootaxa 1646: 31-39. https://doi.org/10.11646/zootaxa.1646.1.3

Moreno F. P. 1889. - Breve reseña de los progresos del Museo de La Plata, durante el segundo semestre de 1888. Boletín del Museo de La Plata 2: 1-44.

PASCUAL R. 1984. - Late Tertiary Mammals of southern South America as indicators of climatic deteroration, in Quaternary of South America and Antarctic Peninsula 2. CRC Press, Boca Raton: 1-30.

Pascual R., Ortiz-Jaureguizar E. \& Prado J. L. 1996. — Land mammals: paradigm for Cenozoic South American geobiotic evolution. Münchner Geowissenschaftliche Abhandlungen 30: 265-318.

RiNGUELET R. A. 1961. — Rasgos fundamentales de la zoogeografía de la República Argentina. Physis 22: 151-170.

Ringuelet R. A. 1975. - Zoogeografía y ecología de los peces de aguas continentales de la Argentina y consideraciones sobre las áreas ictiológicas de América del Sur. Ecosur 2 (3): 1-122.

Terán G. E., Benitez M. F. \& Mirande J. M. 2020. - Opening the Trojan horse: phylogeny of Astyanax, two new genera and resurrection of Psalidodon (Teleostei: Characidae). Zoological Journal of the Linnean Society 190 (4): 1217-1234. https://doi. org/10.1093/zoolinnean/zlaa019

Tomassini R. L., Agnolin F. \& Oliva C. 2011. — First fossil record of the genus Lepidobatrachus Budgett, 1899 (Anura, Ceratophryidae), from the early Pliocene of Argentina. Journal of Vertebrate Paleontology 31 (5): 1005-1009. https://doi.org/10 $.1080 / 02724634.2011 .596602$

Tomassini R. L., Montalvo C. \& Deschamps C. 2013. Biostratigraphy and biochronology of the Monte Hermoso Formation (early Pliocene) at its type locality, Buenos Aires Province, Argentina. Journal of South American Earth Sciences 48: 31-42. https://doi.org/10.1016/j.jsames.2013.08.002

Tonni E. P. 1974. - Un nuevo cariámido (Aves, Gruiformes) del Plioceno Superior de la provincia de Buenos Aires. Ameghiniana 9: 366-372.

VARI R. P. 1979. - Anatomy, relationships and classification of the families Citharinidae and Distichodontidae (Pisces, Characoidea). 
Bulletin of the British Museum (Natural History). Zoology 36 (5): 261-344. https://doi.org/10.5962/bhl.part.3608

Weiss F. E., Malabarba L. R. \& Malabarba M. C. 2012. Phylogenetic relationships of Paleotetra, a new characiform fish (Ostariophysi) with two new species from the Eocene-Oligocene of south-eastern Brazil. Journal of Systematic Palaeontology 10: 73-86. https://doi.org/10.1080/14772019.2011.565082

Weiss F. E., Malabarba M. C. \& Malabarba L. R. 2014. A new stem fossil characid (Teleostei: Ostariophysi) from the
Eocene Oligocene of southeastern Brazil. Neotropical Ichthyology 12: 439-450. https://doi.org/10.1590/1982-0224-20140072

ZanAtA A. M. \& VARI R. P. 2005. — The family Alestidae (Ostariophysi, Characiformes): a phylogenetic analysis of a trans-Atlantic clade. Zoological Journal of the Linnean Society 145: 1-144. https:// doi.org/10.1111/j.1096-3642.2005.00183.x

Zavala C. \& Navarro E. 1993. - Depósitos fluviales en la Formación Monte Hermoso (Plioceno inferior-medio). Provincia de Buenos Aires. Actas V Congreso Geológico Argentino 2: 236-244.

Submitted on 7 August 2019;

accepted on 7 January 2020; published on 2 February 2021. 